DOI: 10.4274/tpa.45.299

\title{
Transvers miyelit tablosu ile getirilen akut dissemine ansefalomiyelit olgusu
}

\section{A case of acute disseminated encephalomyelitis presented with transvers myelitis}

\author{
Avni Kaya, Mustafa Özkan, M. Selçuk Bektaş, Mehmet Açıkgöz, Hayrettin Temel, Ertan Sal, Hüseyin Çaksen* \\ Yüzüncü Yıl Üniversitesi Tıp Fakültesi Araştırma Hastanesi, Çocuk Sağıı̆ı ve Hastalıkları Anabilim Dalı, Van, Türkiye \\ *Yüzüncü Yıl Üniversitesi Tıp Fakültesi Araştırma Hastanesi, Çocuk Sağlığı ve Hastalıkları Anabilim Dalı, Çocuk Nöroloji Bilim Dalı, Van, Türkiye
}

\section{Özet}

Akut dissemine ansefalomiyelit, merkezi sinir sisteminin enflamatuvar, demiyelinizan bir hastalığıdır. Dokuz yaşında erkek hasta iki gün önce başlayan yürüyememe, bacaklarını hissedememe, idrar ve dışkı kaçırma yakınması ile getirildi. Fizik bakısında, üst ekstremitelerde kas gücü 5/5, alt ekstemitelerde $1 / 5$ idi. Her iki alt ekstremitelerden başlayıp T8 düzeyine kadar uzanan yüzeyel duyu kaybı vardı. Spinal manyetik rezonans görüntülemesinde, C3'ten konus medüllarise uzanan ve kontrast madde tutulumu gösteren hiperintens yaygın lezyon saptandı. Elektromiyografi poliradikülonevritle, beyin manyetik rezonans görüntülemesi bulguları akut dissemine ansefalomiyelit ile uyumluydu. Bu olgu dolayısıyla transvers miyelit tablosu ile getirilen hastalarda akut dissemine ansefalomiyelit olabileceğini, bu nedenle spinal manyetik rezonans görüntülemesi yanında kraniyal manyetik rezonans görüntülemesinin de yapılmasının uygun olacağını vurgulamak isteriz. (Türk Ped Arş 2010; 45: 299-302)

Anahtar sözcükler: Akut dissemine ansefalomiyelit, çocuk, transvers miyelit

\section{Summary}

Acute disseminated encephalomyelitis is an inflammatory and demyelinating disorder of central nervous system. A 9-year-old male was admitted with unable to walk, non-sensation of legs, urinary incontinence and encopresis for 2 days. On physical examination, muscle strength was $5 / 5$ on upper extremities and 1/5 on lower extremities. Loss of pain, temperature and touch sensation was present on both lower extremities, reaches to T8 level. On spinal magnetic resonance imaging, diffuse hyperintensity from C3 to conus medullaris was detected. While electromyography was consistent with polyradiculoneuritis, magnetic resonance imaging findings were concordant with acute disseminated encephalomyelitis. On account of this case, we would like to emphasize that acute disseminated encephalomyelitis should be considered in patients presented with transverse myelitis; therefore, in addition to spinal magnetic resonance imaging, cranial magnetic resonance imaging should be examined in these patients. (Turk Arch Ped 2010; 45: 299-302)

Key words: Acute disseminated encephalomyelitis, child, transverse myelitis

\section{Giriş}

Akut dissemine ansefalomyelit (ADEM), merkezi sinir sisteminin ani başlangıçlı, değişken klinik seyir gösteren demiyelinizasyonla giden bir hastalığıdır (1). Aşılanmayı takiben gelişebileceği gibi sık olarak üst solunum yolu enfeksiyonları ve kızamık, kızamıkçık, su çiçeği, herpes zoster, kabakulak ve Mycoplasma pneumoniae enfeksiyonları seyri sırasında da görülebilir (2). Patolojik olarak perivasküler enflamasyon, ödem ve demiyelinizasyonla belirgindir. Klinik olarak, hastalığa özgül olmayan sistemik belirti ve bulgularla sınırlı kalabilir ya da hızlı gelişen fokal ya da mültifokal nörolojik işlev bozukluğu görülebilir (3). Tanı, en iyi manyetik rezonans görüntüleme (MRG) ile yapıIır (4). Bu makalede, transvers miyelit tablosu ile getirilip ADEM tanısı alan dokuz yaşında bir erkek olgu sunulmuştur.

\section{Olgu sunumu}

Daha önce sağlıklı olan dokuz yaşında erkek hasta, iki gün önce başlayan yürüyememe, bacaklarını hissedememe, idrar ve dışkı kaçırma yakınmaları ile getirildi. Öyküsünden iki gün öncesinde önce sol ayağında ve ardından sağ

Yazışma Adresi/Address for Correspondence: Dr. Avni Kaya, Yüzüncü Yıl Üniversitesi Tıp Fakültesi Araştırma Hastanesi, Çocuk Sağlığı ve Hastalıkları Anabilim Dalı, Van, Türkiye E-posta: avnikaya@gmail.com

Geliş Tarihi/Received: 05.05.2009 Kabul Tarihi/Accepted: 18.01.2010

Not: Bu çalışma, 10. Ulusal Çocuk Nörolojisi Kongresinde Poster olarak sunulmuştur.

Türk Pediatri Arşivi Dergisi, Galenos Yayınevi tarafından basılmıştır. / Turkish Archives of Pediatrics, published by Galenos Publishing 
ayağında uyuşma, ağrı ve bacaklarını hissedememe yakınmalarının olduğu, bir gün sonra yürüyememe, idrar ve dışk kaçırma yakınmalarının başladığı öğrenildi. Özgeçmişinde 15 gün önce geçirilen üst solunum yolu enfeksiyonu dışında özellik yoktu. Soy geçmişinde özellik saptanmadı.

Fizik bakısında genel durumu orta, bilinci açık, yaşamsal bulguları normal sınırlarda idi. Antropometrik ölçümleri yaşı ile uyumluydu. Nörolojik bakısında; üst ekstremitelerde kas gücü 5/5, alt ekstemitelerde $1 / 5$ idi. Her iki alt ekstremitelerden başlayıp T8 düzeyine kadar uzanan seviye veren yüzeyel (dokunma, sıcaklık, soğukluk ve ağrı) duyu kaybı mevcuttu. Derin tendon refleksleri üstte normal, alt ekstremitelerde alınamıyordu. Karın cildi refleksi alınamadı. Plantar yanıt iki taraflı fleksör idi. Ense sertliği vardı. Kernig ve Brudzinsky negatif olarak değerlendirildi. Göz dibi bakısı normaldi.

Laboratuvar incelemelerinde; kan sayımı, serum elektrolitleri, böbrek ve karaciğer işlev testleri normaldi. C-reaktif protein normal, eritrosit çökme hızı $40 \mathrm{~mm} / \mathrm{sa}$ idi. Mikrobiyolojik incelemelerden Salmonella, Brucella, heterofil antikor, Mycoplasma pneumoniae antikoru, TORCH, hepatit ve diğer viral belirteçleri (Herpes simlex virus, Epstein-Barr virus, Parvo virus B19, Respiratuvar sinsisyal virüs, İnfluenza virus antijenleri) normal geldi. İdrar kültürü, kan kültürü ve beyin omirilik sıvısı kültüründe üreme olmadı. Beyin omirilik sıvısı gram boyama ve aside dirençli bakteri incelemesinde herhangi bir mikroorganizma görülmedi. Beyin omurilik sıvısının incelemesinde $\mathrm{mm}^{3}$ 'te 22 lenfosit ve 33 nötrofil saptand, protein $47 \mathrm{mg} / \mathrm{dL}$ idi ( $\mathrm{N}=15-45 \mathrm{mg} / \mathrm{dL})$. Radyolojik incelemelerde ön-arka akciğer grafisi ve karın ultrasonografisi normal idi. Elektromiyografide sol alt ekstremitede tibiyal sinir uyarımlı $F$ dalga yanıtı alınamadı. Bulgular ani başlangıçlı poliradikülonevritle uyumlu idi. Elektromiyografi bulgularına göre GuillainBarré sendromu düşünülen hastaya damardan immünoglobulin başlandı. Göbek hizasından itibaren seviye veren duyu kusurunun olması, idrar, dışkı kaçırma ile beraber değerlendirildiğinde hastanın kliniğinin transvers miyelit ya da spinal bölgeye bası yapan kitle ile açıklanabileceği düşünülerek, acil spinal MRG çekildi. Spinal MRG'de C3 düzeyinden konus medüllarise kadar uzanan, spinal kord merkezinde damardan kontrast madde enjeksiyonu sonrası kontrast tutulumu olan ve kordu hafif genişleten T2 serilerde hiperintens yaygın lezyon saptandı (Resim 1). Bunun üzerine transvers miyelit düşünülen olguda damardan immünglobulin kesilerek $30 \mathrm{mg} / \mathrm{kg}$ 'dan yüksek doz steroid tedavisi verildi. Hastada kraniyal tutulum açısından izleminin 15. gününde kraniyal MRG çekildi. Kraniyal MRG'de korpus kallozumda, peri-supraventriküler düzeyde yer yer subkortikal ve yamalı tarzda sinyal artışları izlendi. Kontrast madde enjeksiyonu sonrası lezyonlarda kontrast tutulumu saptanmadı. Bulgular ADEM ile uyumlu idi (Resim 2). Altı hafta sonra kontrol beyin MRG'de subkortikal ve periventriküler bazı lezyonlarda gerileme olduğu gözlendi (Resim 3). Spinal MRG'de görülen lezyonlar- da ise bir gerileme yoktu. İzleminin 11. ayında olan hastada idrar ve dışkı kontrolünün düzeldiği görüldü. Kas gücü üst ekstremitelerde normal, alt ekstremitelerde 2/5 idi. Hastamız yoğun fizik tedavi programı ile birlikte 2 $\mathrm{mg} / \mathrm{kg} / g u ̈ n ' d e n$ prednizolon tedavisi almaya devam etmekte ve polikliniğimizde takip edilmektedir.

\section{Tartışma}

Akut dissemine ansefalomiyelit genellikle post veya paraenfeksiyöz bir hastalık olarak değerlendirilir. Hastaların yaklaşık \%75'inde yakında geçirilmiş üst solunum yolu enfeksiyonu ya da aşılanma öyküsü bildirilmektedir. Bazı çaIışmalar kış ve ilkbaharda ADEM'in daha sık olduğuna dair mevsimsel özellik bildirmektedir (5). Olgumuzun benzer şekilde 15 gün önce üst solunum yolu enfeksiyonu geçirdiği öğrenildi. Hastamızın kliniği literatürle uyumlu olarak Şubat ayında gözlendi. Akut dissemine ansefalomiyelit tanısı alan 42 çocuk ve ergenin verilerine dayanan bir çalışmada sıklık yılda 0,4/100 000 bulunmuş; cinsiyet, yaş grubu, etnik grup, coğrafik bölge açısından anlamlı farklılık saptanmamıştır (3). Klinik bulgular ile MRG'deki lezyonların yeri arasında ilişki yoktur (6). İlginç olarak MRG'deki lezyonların ciddiyeti ile bulgular arasında da ilişki yoktur (7).

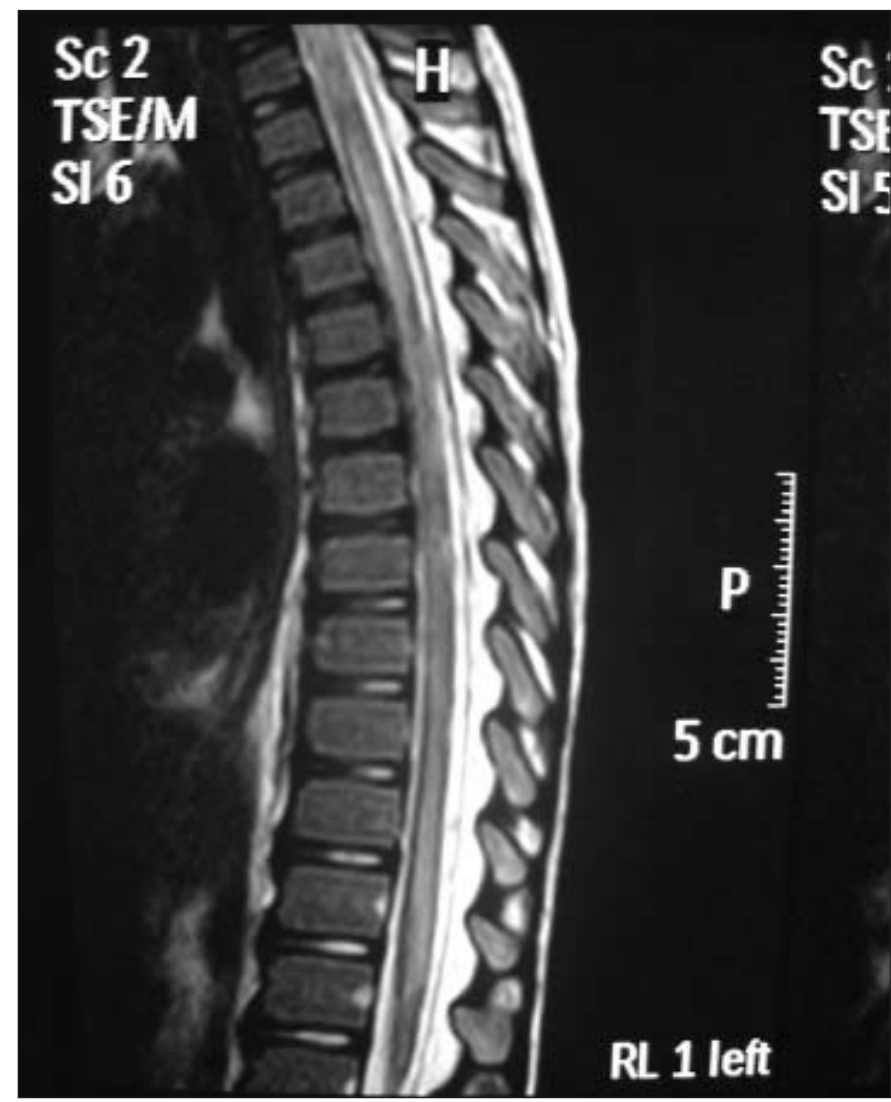

Resim 1. Spinal kord merkezinde damardan kontrast madde enjeksiyonu sonrası kontrast tutulumu ve kordu hafif genişleten T2 serilerde hiperintens yaygın lezyon alanı 
Akut dissemine ansefalomiyelit tipik olarak 2-4 hafta süren, monofazik bir hastalık olarak tanımlansa da tekrarlayabilir $(2,6)$. Hastamızda gözlenen durum ilk ataktır. Beyin omurilik sıvısı bulguları \%25-75 hastada normaldir (3). Artmış beyin omirilik sıvısı basıncı, lenfositik pleositoz $\left(1000 / \mathrm{mm}^{3}\right.$ 'e kadar, bazen başlangıç döneminde polimorf nüveli lökosit artıŞı), protein artışı saptanabilir (8). Olgumuzun beyin omurilik sıvisının incelemesinde $\mathrm{mm}^{3}$ 'te 22 lenfosit ve 33 nötrofil ve hafif yüksek protein saptandı. Elektromiyografi bulgusuna göre Guillan Barré sendromu düşünülen hastaya ilk doz immünuglobülini verildi. Tranvers miyelit spinal kanalda yer kaplayan lezyonlarla karışabileceğinden ve genelde aynı kliniği verdiklerinden ayırıcı tanıda ilk ve acil olarak yapılması gereken hem spinal kord basısının hem de transvers myelitin saptanması için spinal MRG görüntülemesidir.

Akut dissemine ansefalomiyelit tanısı klinik ve beyin MRG görüntülenmesi ile konur. Manyetik rezonans görüntülemede görülen lezyonlar genellikle geniștir ve simetrik değildir. Lezyonlar genellikle çok sayıda olup, bu durumda daima iki taraflı yerleşim gösterir. Lezyonların dağılım yerleri oldukça farklıdır (9). Hastamızda korpus kallozumda, peri-supraventriküler düzeyde yer yer subkortikal ve yamalı tarzda sinyal artışları izlendi, lezyonlarda kontrast tutulumu saptanmadı.

Akut dissemine ansefalomiyelit olgularını \%70'ten fazlasında ilk altı ayda iyileşme görülür (8). Hastalarda \%11-30 arası değişen derecelerde nörolojik sekel kalabilir. Sekel oranı, büyük ya da iki taraflı talamus lezyonu olanlarda da-

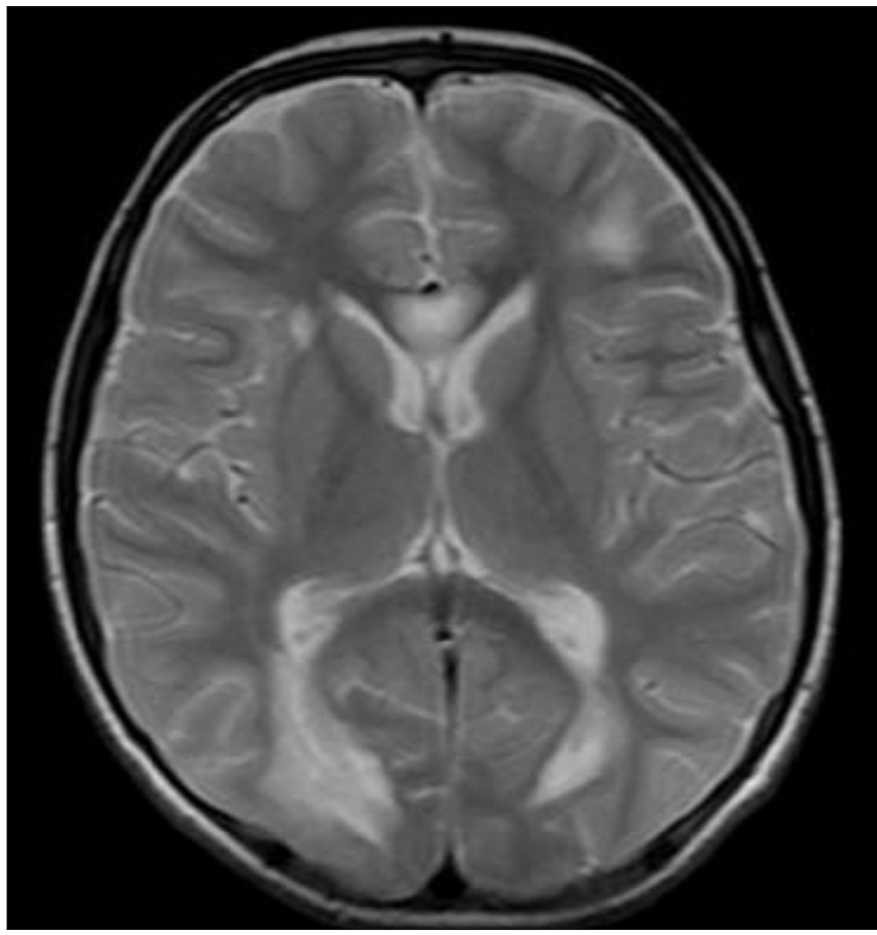

Resim 2. T2 serilerde kraniyal MRG'de korpus kallozumda, peri-supraventriküler düzeyde yer yer subkortikal ve yamalı tarzda sinyal artışları ha yüksektir (8). Hastamızda talamus tutulumu yoktu. Altı hafta sonra kontrol beyin MRG'de subkortikal ve periventriküler bazı lezyonlarda gerileme olduğu gözlendi (Resim 3). Spinal MRG'de görülen lezyonlarda ise bir gerileme yoktu. Hastalıktan ölüm oranı \%10-20 kadar yüksek olabilmekle birlikte, çoğu hasta tamamen iyileşir (10).

Akut dissemine ansefalomiyelit tanısı konan hastalara 3-5 gün yüksek doz metil prednizolon ( $20-30 \mathrm{mg} / \mathrm{kg} / \mathrm{gün}$ ) damardan başlanır. Klinik bulguların gerilemesine bağlı olarak bu tedavinin ardından ağızdan prednizolon 2 $\mathrm{mg} / \mathrm{kg} / \mathrm{gün}$ dozunda başlanıp, 4-6 haftada giderek azalan dozlarda devam edilebilir (4). Hastamıza üç gün 30 $\mathrm{mg} / \mathrm{kg}$ 'dan ve dört gün $20 \mathrm{mg} / \mathrm{kg}$ 'dan yüksek doz metilprednizolon verildi. Ardından 2 mg/kg/gün ağızdan prednizolon tedavisi verilerek izleme alındı. Olgu izlemin 11. ayındadır. Halen ilaç tedavisi almaktadır. Tedaviye yeterli yanıt alınmaması durumunda plazmaferez ya da damardan immünglobülinler diğer bir seçenek olarak düşünülebilir (7). Akut dissemine ansefalomiyelitli hastalarda atak sayısı ve hasta yaşı ile kötü seyir arasında ilişki olduğu sanılmaktadır. Yaş küçüldükçe ve atak sayısı arttıkça seyir kötüleşmektedir (11). Manyetik rezonans görüntülemenin ADEM tanında önemli yeri olmasına rağmen, atağın erken döneminde normal olabileceği bilinmelidir (12).

Bu olgu dolayısıyla, transvers miyelit tablosu ile getirilen hastalarda ADEM olabileceği, uygun tedavi ve işlemin planlanması açısından, spinal MRG yanında kraniyal MRG'nin de çekilmesinin uygun olacağını vurgulamak isteriz.

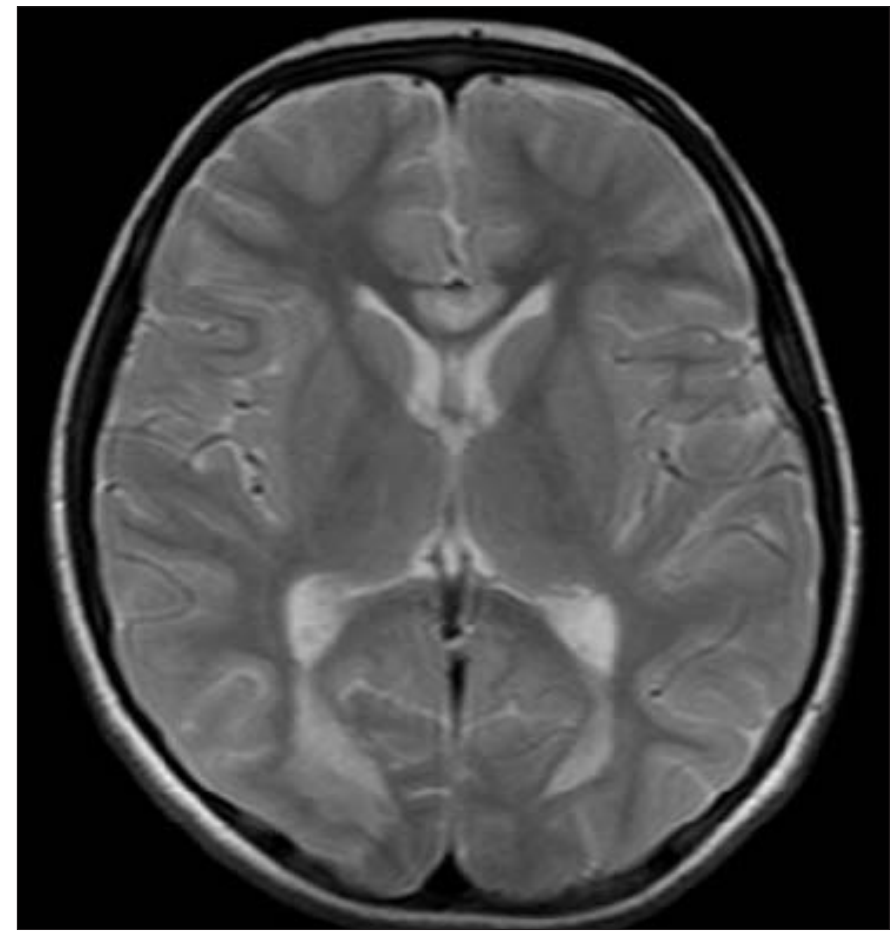

Resim 3. Altı hafta sonra kontrol beyin MRG'da T2 serilerde subkortikal ve periventriküler bazı lezyonlarda gerileme 


\section{Kaynaklar}

1. Rosman NP, Gottlieb SM, Bernstein CA. Acute hemorrhagic leukoencephalitis: recovery and reversal of magnetic resonance imaging findings in a child. J Child Neurol 1997; 12: 448-54. Abstrac / PDH

2. Johnston MV. Demyelinating disorders of the central nervous system. In: RM Kliegman, RE Behrman. HB Jenson, BF Stanton (eds). Nelson Textbook of Pediatrics 18 th edition. Philadelphia: WB Saunders, 2007; 2505-7.

3. Leake $A D$, Albani $S$, Kao $S A$, et al. Acute disseminated encephalomyelitis in childhood: epidemiologic, clinical and laboratory features. Pediatr Infect Dis J 2004; 23: 756-64. (Abstract)

4. Stonehouse B, Gupte G, Wassmer E, Whitehouse WP. Acute disseminated encephalomyelitis: recognition in the hands of general paediatricians. Arch Dis Child 2003; 88: 122- 4. Abstract / Full Text / PDA

5. Yeh EA, Collins A, Cohen ME, Duffner PK, Faden H. Detection of coronavirus in the central nervous system of a child with acute disseminated encephalomyelitis. Pediatrics 2004; 113: 73-6. Abstract / Full Text / DDF
6. Hynson JL, Kornberg AJ, Coleman LT, Shield L, Harvey AS, Kean MJ. Clinical and neuroradiologic features of acute disseminated encephalomyelitis in children. Neurology 2001; 56: 1308-12. [Abstract/ Full Text] PPDA

7. Rajesh B, Preeti S, Vishali M, Mamta V. Acute disseminated encephalomyelitis. Indian J Pediatr 2004; 71: 1035-8.

8. Alper G, Schor NF. Toward definition of acute disseminated encephalitis of childhood. Curr Opin Pediatr 2004; 16: 637-40. (Abstract)

9. Andreula CF, Angelo NM, Recchia L, Milella D. MRI in the diagnosis of acute disseminated encephalomyelitis. Int $\mathrm{J}$ Neuroradiol 1997; 3: 21-34.

10. Lidia V, Gabis MD, Panasci DJ, Andriola MR, Huang W. Acute disseminated encephalomyelitis: an MRI/MRS longitudinal study. Pediatr Neurol 2004; 30: 324-9. [Abstract) / Full Text/ (PDF)

11. Kabakuş N, Çıtak NA, Kurt A. Akut dissemine ensefalomyelit: klinik seri. Fırat Tıp Dergisi 2005;10: 127-31. AAbstract / Full Tex/PD/

12. Murthy SN, Faden HS, Cohen ME, Bakshi R. Acute disseminated encephalomyelitis. Pediatrics 2002; 110: e21. 